\title{
BIO-COMPOSITES WITH LEATHER FIBERS AND CEMENT - PHYSICO-MECHANICAL AND STRUCTURAL CHARACTERIZATION
}

\section{Gabriel ZĂINESCU ${ }^{1}$, Viorica DESELNICU ${ }^{1 *}$, Roxana CONSTANTINESCU ${ }^{1}$, Claudiu CIULACU ${ }^{2}$}

${ }^{1}$ National R\&D Institute for Textiles and Leather - Division: Leather and Footwear Research Institute, 93 lon Minulescu st., 031215, Bucharest, Romania, e-mail: icpi@icpi.ro

${ }^{2}$ S.C. PROCEMA - Cercetare SRL, 6R Preciziei st., sector 6 Bucharest, Romania, e-mail: office@ procema-cercetare.ro

Received: 09.10.2018

Accepted: 13.12 .2018

https://doi.org/10.24264/Ifj.18.4.8

\section{BIO-COMPOSITES WITH LEATHER FIBERS AND CEMENT - PHYSICO-MECHANICAL AND STRUCTURAL CHARACTERIZATION}

ABSTRACT. Circular economy systems keep the added value in products for as long as possible and eliminate waste. Resources are kept within the economy when a product has reached the end of its life, so that they can be productively used again and again and hence create further value. In this context, the specialists from leather and footwear sector look for innovative solutions for utilization of leather wastes for obtaining of new bio-composites with application in construction industry. This paper presents utilization of leather wastes for obtaining construction materials for pedestrian walkways (paving blocks) containing leather fibers obtained from leather waste and their physicalmechanical and structural characterization.

KEY WORDS: leather waste, leather fibers, concrete, bio-composite

BIO-COMPOZITE CU FIBRE DE PIELE ȘI CIMENT - CARACTERIZARE FIZICO-MECANICĂ ȘI STRUCTURALĂ

REZUMAT. În economia circulară, sistemele mențin valoarea adăugată a produselor cât mai mult timp posibil și elimină deșeurile. Resursele se păstrează în cadrul economiei atunci când un produs a ajuns la sfârșitul vieții sale, astfel încât să poată fi folosit din nou și din nou și, prin urmare, să creeze o valoare suplimentară. În acest context, specialiștii din sectorul pielăriei și încălțămintei caută soluții inovatoare pentru utilizarea deșeurilor de piele pentru obținerea unor noi bio-compozite cu aplicații în industria construcțiilor. Această lucrare prezintă utilizarea deșeurilor de piele pentru obținerea materialelor de construcție pentru pavele pietonale care conțin fibre de piele obținute din deșeurile de piele și caracterizarea fizico-mecanică și structurală a acestora.

CUVINTE CHEIE: deșeuri de piele, fibre de piele, beton, bio-compozite

BIO-COMPOSITES AVEC DES FIBRES DE CUIR ET DE CIMENT - CARACTÉRISATION PHYSICO-MÉCANIQUE ET STRUCTURELLE

RÉSUMÉ. Les systèmes d'économie circulaire conservent la valeur ajoutée des produits le plus longtemps possible et éliminent les déchets. Les ressources sont conservés dans l'économie lorsqu'un produit est en fin de vie, de sorte qu'il peut être utilisé encore et encore, créant ainsi une valeur ajoutée. Dans ce contexte, le spécialiste du secteur du cuir et de la chaussure recherche des solutions innovantes pour l'utilisation des déchets de cuir afin d'obtenir de nouveaux bio-composites destinés au secteur de la construction. Cet article présente l'utilisation des déchets de cuir pour obtenir des matériaux de construction pour les chaussées piétonnes contenant des fibres de cuir dérivées de déchets de cuir et leur caractérisation physico-mécanique et structurelle.

MOTS CLÉS : déchets de cuir, fibres de cuir, béton, bio-composites

\footnotetext{
* Correspondence to: Viorica DESELNICU, National R\&D Institute for Textiles and Leather - Division: Leather and Footwear Research Institute, 93 Ion Minulescu st., 031215, Bucharest, Romania, e-mail: icpi@icpi.ro
} 


\section{INTRODUCTION}

\section{European Leather Sector}

Europe is an important player in the international leather trade. With some $25 \%$ of the world's leather production and one of the largest and most dynamic consumer markets for leather articles, Europe stands out as the leading force in international business circles in relation to leather and tanning.

With a turnover of nearly $€ 8$ billion, over 3000 companies and some 50000 people directly employed in the sector, Europe's tanneries demonstrate their competitiveness on the global market. Their products are renowned and appreciated by manufacturers worldwide for their quality and fashionable designs. European leathers are exported all over the world to satisfy the highest standards, the most stringent ecological regulations and the increasing expectations of quality aware consumers [1].

Tanners in Europe have a long tradition of producing all kinds of leather, from bovine and calf leather to sheep and goat leather, from sole and exotic specialities to double-face garment leather. Their expertise contributes to the success of leading footwear, garment, furniture and leather goods manufacturers (Figure 1). This solid experience and the outstanding know-how of European tanners and dressers is displayed at major international fairs. All this explains the continuously strong demand for their products on international markets.

The European leather industry is committed to a socially and environmentally sustainable development.

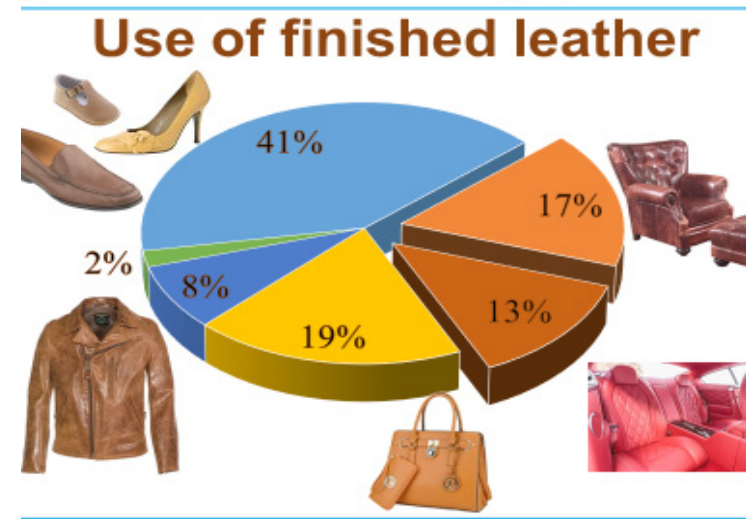

Figure 1. The current use of finished leather [2]
The depollution task associated to leather processing activities falls into the range of medium to high difficulty. Solid wastes (wastes from tanned and not tanned hides and sludge resulting from waste water treatment) represent a big problem of the leather sector. In tanneries, only about one third of the total mass of starting materials (hides and skins) is converted into leather, while the two thirds occur either as dissolved or solid wastes [3].

From the total mass of hides and skins, nearly 4.4 mill tons (EU 700000 tons) of solid waste (moisture content $70-80 \%$ ) with a content of over 1.2 mill tons (EC 190000 tons) of utilizable dry proteins will occur. Only a part of these proteins have been utilized so far, especially for animal nutrition, but the EC - legislation (due to BSE - crisis) has closed this line (except few still permitted applications). Since the utilization of the mentioned solid tannery wastes is, so far, only possible to a limited extent, the problem of disposal is already evident in EU [4], in USA [5] or will arise in the near future for the developing countries as Romania. A pure incineration is not feasible due to an insufficient energy yield (high drying costs) and the formation of Green House Gases $\left(\mathrm{CO}_{2}\right.$, NOx). On the other hand, collagen (main component of fleshings, trimmings and shavings) is a protein with several functional groups (-CO-NH-, - $\mathrm{OH},-\mathrm{NH}_{2}$ and $-\mathrm{COOH}$ ) and shows - after treatment - excellent reactivity and glueing properties. Large European tanneries and clusters already perform a separation of fleshings into fat and protein [6] or transfer their wastes to specialized companies (e.g. SICIT S.p.a., Chiampo/ Vicenza, Italy), where they produce from the resulting hydrolysates various fertilizers, some (low-value) auxiliaries for leather [7] and textile. All these treatments lead to rather heterogeneous hydrolysates, and so their further application is limited. The major share of fleshings is still incinerated (in EU).

The footwear industry is a diverse manufacturing sector that utilizes a wide variety of materials to manufacture products ranging from different types and styles of footwear to specialized shoes. Leather, synthetic materials, rubber, and textiles are among the most commonly used basic materials in footwear 
manufacturing, each material having its own characteristics. Materials significantly affect not only the life of footwear, but also treatment at the end of product life. About 40 different materials are used in footwear manufacturing [8]. Of these, leather has the highest percentage (25\%) [9].

In recent years the footwear industry has made significant efforts to improve the efficiency of energy and material consumption, as well as to eliminate the use of hazardous materials in the manufacturing phase. However, the advantages gained in production in terms of environmental protection and improving efficiency of energy use are outweighed by the significant increase in demand for footwear products, the so-called "boomerang" effect [10].

To meet customer needs and to be competitive at the same time, footwear companies have to face two key challenges: to respond quickly to market changes and remain interested in changes in order to identify or establish new trends in consumption. These lead to a shorter life cycle of shoes, and even to a shorter product development cycle for the footwear industry. A lower life cycle for shoes means a higher yield over time, resulting in an increased amount of waste from the footwear sector.

The worldwide footwear production resumed growth in 2017 reaching 23.5 billion pairs, $2 \%$ more than in the previous year. Although this is still far from the fast growth pace registered between 2010 and 2014 $(+15.4 \%)$, it represents a return to a positive dynamic. In terms of its geographic distribution, production continues to be heavily concentrated in Asia where $87 \%$ of all pairs of footwear are manufactured. China remains in pole position at the head of the table of the 10 largest footwear consumers where 3 other Asian countries also appear: Pakistan, Japan and Indonesia. These 5 Asian countries represent almost $40 \%$ of world consumption. Two thirds of the total European footwear production is focused on three countries, namely: Italy, Spain and Portugal. Italy alone is responsible for approximately 50 percent of production. [11].

\section{Circular Economy}

The European Commission adopted in 2016 an ambitious Circular Economy Package, which includes measures that will help stimulate Europe's transition towards a circular economy, boost global competitiveness, foster sustainable economic growth and generate new jobs [12-15].

The Circular Economy Package consists of an EU Action Plan for the Circular Economy that establishes a concrete and ambitious programme of action, with measures covering the whole cycle: from production and consumption to waste management and the market for secondary raw materials and a revised legislative proposal on waste. The proposed actions will contribute to "closing the loop" of product lifecycles through greater recycling and re-use, and bring benefits for both the environment and the economy.

In a circular economy [16], products and the materials they contain are valued highly, unlike in the traditional, linear economic model, based on a 'take-make-consume-throw away' pattern. In practice, a circular economy implies reducing waste to a minimum as well as reusing, repairing, refurbishing and recycling existing materials and products. What used to be considered as 'waste' can be turned into a valuable resource.

Moving towards a more circular economy could deliver benefits, among which reduced pressures on the environment, enhanced security of supply of raw materials, increased competitiveness, innovation, and growth and jobs. However, it would also face challenges, among which finance, key economic enablers, skills, consumer behaviour and business models, and multi-level governance.

The revised legislative proposals on waste $[17,18]$ set clear targets for reduction of waste and establish an ambitious and credible longterm path for waste management and recycling. One of key element of the revised waste proposal include: Concrete measures to promote re-use and stimulate industrial symbiosis - turning one industry's by-product into another industry's raw material.

Circular economy systems keep the added value in products for as long as possible and 
eliminate waste. They keep resources within the economy when a product has reached the end of its life, so that they can be productively used again and again and hence create further value. Transition to a more circular economy requires changes throughout value chains, from product design to new business and market models, from new ways of turning waste into a resource to new models of consumer behaviour (Figure 2)

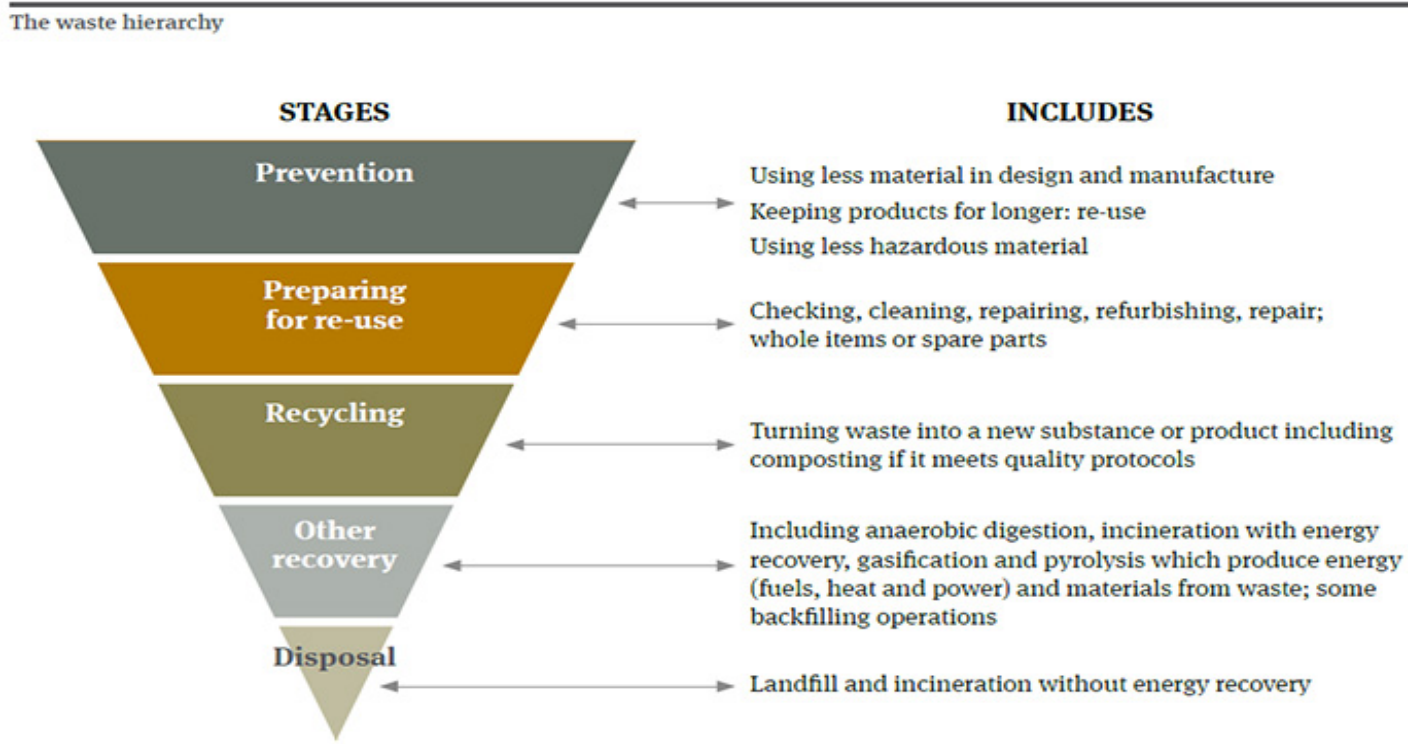

Figure 2. The waste hierarchy [19]

Natural leather fiber reinforced polymers are commonly used in the automotive and construction industry because natural fibers exhibit many advantageous properties such as low weight, low cost, low density, high specific properties and availability from renewable resources [20].

In the same research line, leather fibers can be easily modified with different kinds of polymeric resins. These modified leather fibers can be used in cement based matrices for improvement of tensile strength, toughness and multi-cracking behavior. Because of its natural properties and especially thermal efficiency, leather is an excellent insulation and reinforcing material. The physical properties which make leather a unique and valuable material for different purposes includes: high tensile strength; resistance to tear; high resistance to flexing; good heat insulation; resistance to heat and flame; resistance to mildew; resistance to chemical attack (the atmosphere of modern cities is polluted from the burning of carbon fuels with sulphur dioxide gas, which can accelerate the deterioration of leather; modern leathers are tanned and dressed to resist these harmful chemicals).

Many studies relates utilization of leather waste as raw material for construction materials. In the project TAIMEE (2012-2015) [21], the production and market implementation of an innovative leather composite material which has thermal insulation properties in addition to acoustical isolation properties for immediate application in building sector have been produced and market implemented. Other studies [22-31] relate utilization of leather waste to make light weight concrete and biocomposites for use in construction.

The aim of this paper is to present an innovative production model in the context of the Circulation Economy concept. The main objective is to re-evaluate leather waste from the leather sector by turning it into value-added raw material and use it in the construction materials industry by developing new technologies. 


\section{EXPERIMENTAL}

\section{Materials}

\section{Preparation of Leather Fibers}

The leather shavings used in this work as raw material for obtaining of paving blocks were obtained from Pielorex-SA Jilava-Ilfov tannery.

The leather waste was cut using a knife mill equipped with a metal sieve with meshes of 6-9 $\mathrm{mm}$ in diameter, resulting in pieces of waste with a surface area of max. $0.5-0.6 \mathrm{~cm}^{2}$, transported to the storage room, where they are loaded into bags. The leather wastes before grinding were hand-picked with a permanent magnet. An amount of $1500 \mathrm{~g}$ of leather fibers was dispersed in $2 \mathrm{~L}$ water and was subjected to hydrolysis with $1-2 \%$ concentrated sulfuric acid solution based on the weight of the leather fibers, at a temperature of $30-50^{\circ} \mathrm{C}$ for 60 minutes. Then $0.4-0.9 \%$ organic polymer binder used in the field of synthetic foil and fiber is poured over leather fibers. This polymer has the role of encapsulating the fibers in a polymeric "shirt". The leather fibers (PFA) are obtained with physical-chemical characteristics presented in Table 1.

Table 1: Physical- chemical characteristics of leather fibers treated with acid (FPA)

\begin{tabular}{lccl}
\hline \multicolumn{1}{c}{ Characteristics } & UM & FPA & Standard Method \\
\hline Dry substance & $\%$ & 8.53 & SR EN ISO 4684 : 2006 \\
Ashes & $\%$ & 18.29 & SR EN ISO 4047 : 2002 \\
Total nitrogen & $\%$ & 12.66 & SR ISO 5397 : 1996 \\
Dermal substance & $\%$ & 71.15 & SR ISO 5397 : 1996 \\
Chromium oxide & $\%$ & 5.16 & SR EN ISO 5398/1 :2008 \\
pH & pH units & 1.78 & STAS 8619/3 :1990 \\
Calcium Oxide & $\%$ & 0.23 & \\
\hline
\end{tabular}

Values for ash, total nitrogen and dermal substance are reported as free from volatile matter

\section{Production of Paving Blocks}

Paving blocks for use in pedestrian walkways have been obtained by utilization of $1 \%$ and $3 \%$ respectively of treated leather fibers (FPA) following technological process scheme presented in the Figure 1 to obtain high-density concrete (vibrating concrete), based on receipt of S.C. PAV-Consult SRL-Glina-Popesti Leordeni factory $[28,30]$.

A quantity of $20 \mathrm{~m}^{2}$ of paving blocks containing $1 \%$ and $3 \%$ leather fibers were made. Paving blocks with FPA have the dimensions of $280 \times 230 \times 25 \mathrm{~mm}$. 


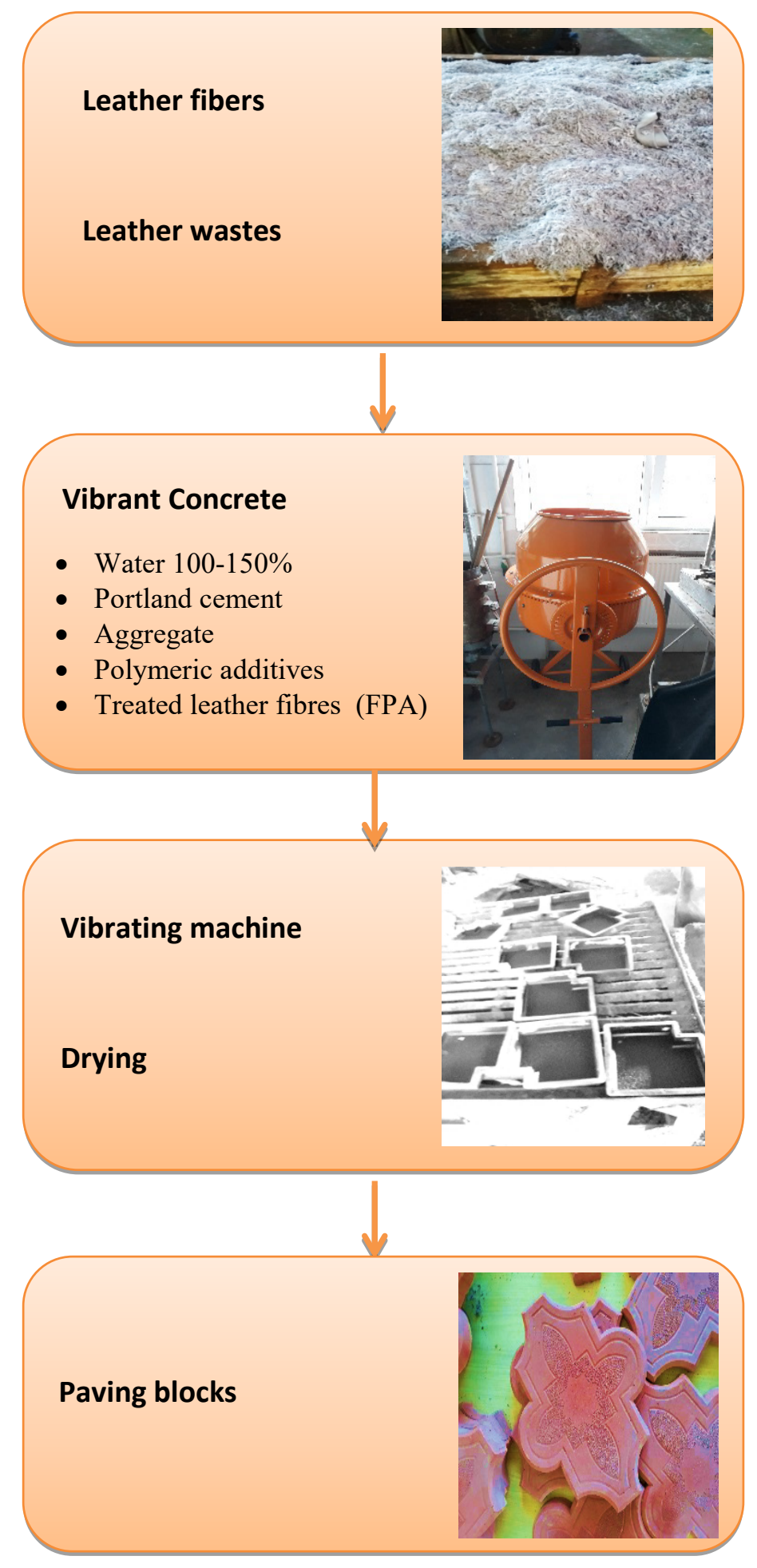

Figure 3. Technological process scheme for obtaining paving blocks with leather fibers (FPA)

\section{Methods}

The paving blocks with leather fibers (FPA) made by the technological process of making concrete with vibrating compaction (for pavements) were compared with production of low-density concrete (fluid).

\section{Physical-Mechanical Characteristics}

Paving blocks with FPA were analyzed by a specialized laboratory, PROCEMA Cercetare SRL Bucharest (www.procema-cercetare.ro), for physical-mechanical characteristics. 
The tensile strength and resistance to action of climatic factors, namely the determination of water absorption, have been measured according to SR EN 1338:2004/AC:2006 - Concrete pavements. Test conditions and methods according to the procedure: PS-LI 01.

The equipment used for measuring the tensile strength was CONTROLS 04074755 Type: 50 - C56W2 - a compression-bending test system for concrete with compression measuring ranges of 1: $150 \mathrm{kN}$ and another of 0: $3000 \mathrm{kN}$.

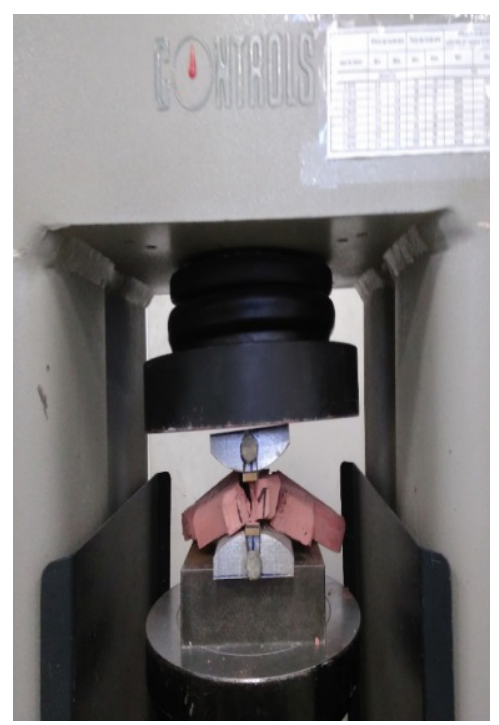

Figure 4. Determination of tensile strength by splitting with CONTROLS 50 - C56W2 system

\section{Microstructural Characterization of Paving Blocks}

Microstructural characterization was performed by SEM-EDAX scanning electron microscopy. The samples were analyzed at the
Institute for Macromolecular Chemistry "Petru Poni" in lasi using a Zeiss DSM 940-A scanning electron microscope, with a voltage of $25 \mathrm{kV}$ and a distance of $15 \mathrm{~mm}$.

\section{RESULTS AND DISCUSSIONS}

\section{Organoleptic Analysis}

As far as the visual aspect is concerned, all analyzed samples of paving blocks have no visible defects (cracks, material detachments), and the texture is uniform of both exposed and tear sections after the splitting test. Also the samples have no color variation on each sample or between different samples.

\section{Tensile Strength by Splitting}

Physical-mechanical analysis of paving block samples with FPA fiber, labeled 729 PB-4 (containing 1\% FPA), 729 PB-7 (containing 3\% PFA) and with 729 PB-M2 (without leather fiber FPA) were performed.

Table 2 presents the results of tensile strength by splitting for the samples with leather fibers compared with control sample without leather fibers. The results obtained by the splitting test indicate a good behavior for the samples with the addition of leather waste (especially for sample 729 PB - 4).

Figure 3 presents images of the specimens after measurement of tensile strength by splitting. Small pieces of leather fibers can be observed in cross section of specimens.

Table 2: Results obtained for tensile strength by splitting

\begin{tabular}{|c|c|c|c|}
\hline Characteristics & U.M. & Results & Method \\
\hline \multicolumn{4}{|l|}{ Sample Code: 729PB - M2 } \\
\hline Tensile strength by splitting - $\mathrm{T}$ & $\mathrm{N} / \mathrm{mm}$ & 3,5 & \\
\hline Load /unit of length - F & $\mathrm{MPa}$ & 230 & \\
\hline \multicolumn{4}{|l|}{ Sample Code: 729PB - 4} \\
\hline Tensile strength by splitting - $\mathrm{T}$ & $\mathrm{N} / \mathrm{mm}$ & 5,0 & \multirow{5}{*}{$\begin{array}{c}\text { SR EN 1338:2004/ AC:2006 } \\
\text { Annex F PS-IF-06 }\end{array}$} \\
\hline Load /unit of length - F & $\mathrm{MPa}$ & 332 & \\
\hline \multicolumn{3}{|l|}{ Sample Code729PB- } & \\
\hline Tensile strength by splitting - $\mathrm{T}$ & $\mathrm{N} / \mathrm{mm}$ & 3,3 & \\
\hline Load / unit of length - F & $\mathrm{MPa}$ & 221 & \\
\hline
\end{tabular}



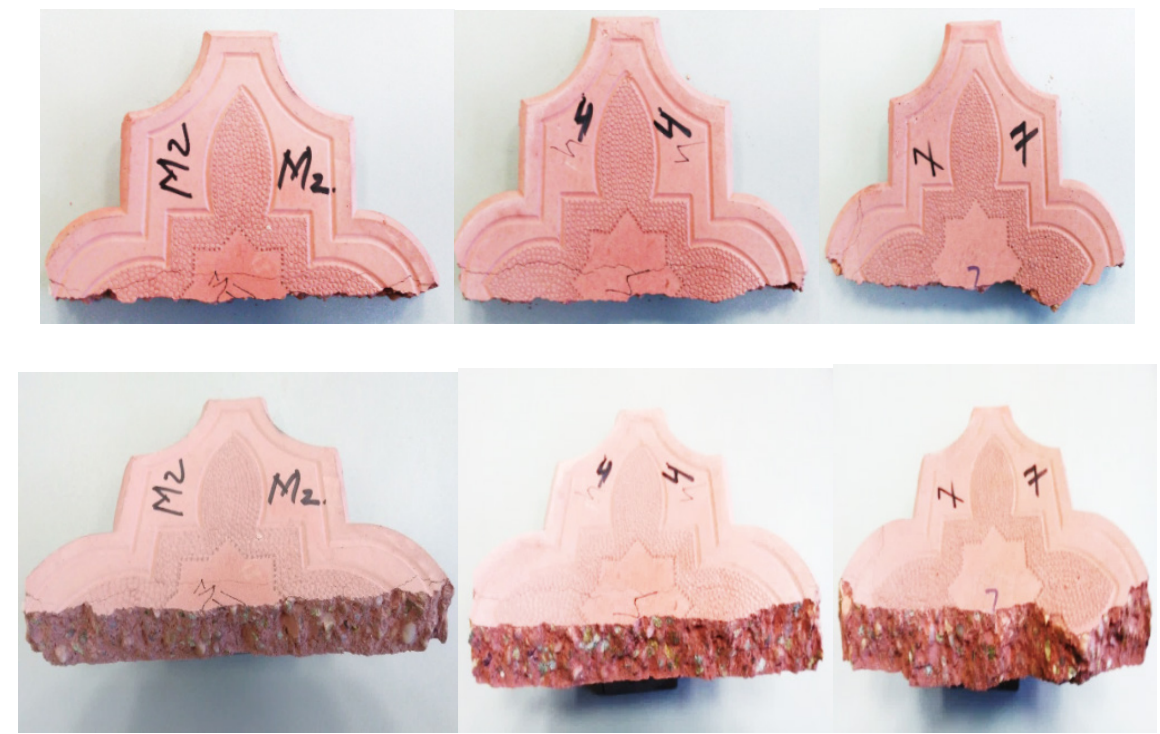

Figure 5. Images of the specimens after measurement of tensile strength by splitting

\section{Resistance to Action of Climatic Factors (Water Absorption)}

Table 3 presents the results of resistance to action of climatic factors (water absorption).

Table 3: Resistance to action of climatic factors (water absorption)

\begin{tabular}{ccc}
\hline Characteristics & Water absorption, \% & Method \\
\hline Sample Code: 729PB - M2 & 8,1 & SR EN 1338:2004/ AC:2006 \\
Sample Code: 729PB - 4 & 7,1 & Annex E PS-IF-06 \\
Sample Code: 729PB - 7 & 7,2 & \\
\hline
\end{tabular}

With regard to the physical characteristics of the climatic factors, namely the determination of the water absorption, a uniform behavior is observed in the two samples with leather fibers FPA compared to the control sample. This characteristic, i.e. determination of the water absorption, is very important because the small values denote that they will be more resistant to the action of climatic factors and especially to the action of the frost-thaw phenomenon.

\section{SEM-EDAX Microscopy}

By analyzing the specimens by SEM-EDAX (Figure 4) it is observed that the images of the samples with content of leather fibers (P4 and P7) show surfaces' structure with a large number of portlandite plates (silicon and calcium), reducing the amount of silicified water crystals and consequently, it results in an increase of splitting resistance - a main characteristic of concrete pavements. 

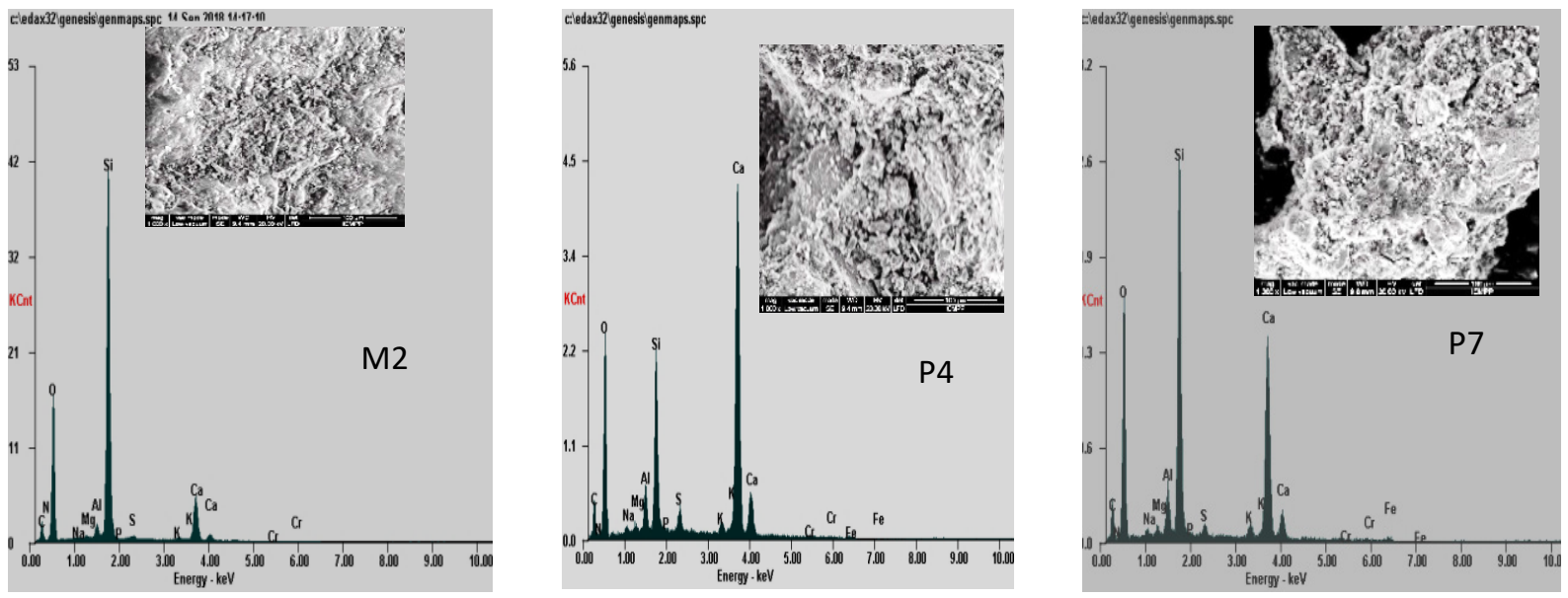

6. SEM-EDAX microscopy for control (M2) and samples P4 and P7 of biocomposites

\section{CONCLUSION}

This paper presented a new production concept in order to develop bio-based composites with improved properties with application in construction materials. This transformation of an actual waste into new value-added products will lead to remarkable life-cycle-improvements of the starting materials and will close loops in terms of sustainable utilization of former wastes, increasing the eco-efficiency and economic efficiency of leather and footwear sector.

\section{Acknowledgement}

This work was financially supported by $\mathrm{MCl}$, in the frame of Nucleu Program 2018 project code PN 18230103 "Bioconversion of leather waste into raw materials to obtain biocomposites with low environmental impact", contract no. $16 \mathrm{~N} / 16.03 .2018$.

\section{REFERENCES}

1.https://www.euroleather.com/index.php/ cotance/the-european-leather-industry.

2.https://ec.europa.eu/growth/sectors/fashion/ leather_en.

3. Buljan, J., Kral, I., Benchmarking in the Tanning Industry, UNIDO, 2012, available at https://leatherpanel.org/sites/default/files/ publications-attachments/benchmarking_ final_d2012.pdf.

4. Tobler-Rohm, M., Sustainable development in enterprises, ETH Zurich, 2002.

5. Patent US4152323A, Process for removing water from glue stock, 1979.
6. Andres, $\mathrm{H}$. et al., Entsorgung von Maschinleimleder, Das Leder, 1988, 39.

7. Santos, L.M., Gutterres, M., Reusing of a hide waste for leather fatliquoring, J Clean Prod, 2007, 15, 1, 12-16, https://doi.org/10.1016/j. jclepro.2006.01.025.

8. Harvey, A., Footwear Materials and Process Technology, Lasra Publications, New Zealand, 1982.

9. UNIDO, Wastes Generated in the Leather Footwear Industry, 14th Session of the Leather and Leather Products Industry Panel, 2000.

10. Binswagner, M., Technological Progress and Sustainable Development: What About the Rebound Effect? Ecol Econ, 2001, 36, 119-132, https://doi.org/10.1016/S09218009(00)00214-7.

11. The 2018 edition of the World Footwear Yearbook, published by the Portuguese Footwear Association, APICCAPS, 2018.

12. https://www.oecd.org/env/outreach/ECCircular-econonomy.pdf.

13. Deselnicu, D.C., Militaru, G., Deselnicu, V., Zăinescu, G., Albu, L., Towards a Circular Economy- a Zero Waste Programme for Europe, Proceedings of the 7th ICAMS 2018, 563-569, 18-20 October 2018, Bucharest, https://doi.org/10.24264/icams-2018.XI.4.

14. Deselnicu, V., Zăinescu, G., Albu, L., Deselnicu, D.C., Militaru, G., Pang, X., Circular Economy - An Innovative and Creative Production Model, Proceedings of the 7th ICAMS 2018, 569-575, 18-20 October 2018, Bucharest, https://doi.org/10.24264/icams-2018.XI.5. 
15. Deselnicu, D.C., Militaru, G., Deselnicu, V., Zăinescu, G., Albu, L., Sustainable Development in the Frame of the 7th Environment Action Programme, Proceedings of the 7th ICAMS 2018, 557-563, 18-20 October 2018, Bucharest, https://doi. org/10.24264/icams-2018.XI.3.

16. EPRS-Circular economy package, 2016, available at http://www.europarl.europa. eu/EPRS/EPRS-Briefing-573936-Circulareconomy-package-FINAL.pdf.

17. http://ec.europa.eu/environment/waste/ target_review.htm.

18. Directive 2008/98/EC of the European Parliament and of the Council, November 2008.

19. Waites, J., Nexus - A global Infrastructure Resource, Chapter 6 - The Circular Economy Revolution: the Future of Waste Processing for Europe, London, May 2015, pp. 44.

20. Manfredi, L.B., Rodriguez, E.S., WladykaPrzybylak, M., Vázquez, A., Thermal degradation and fire resistance of unsaturated polyester, modified acrylic resins and their composites with natural fibres, Polym Degrad Stab, 2006, 91, 255-255, $\quad$ https://doi.org/10.1016/j. polymdegradstab.2005.05.003.

21. *** EU project, Thermal and Acoustic Insulating Material from Finished Leather Waste, TAIMEE, 2012-2015.

22. ${ }^{* * *}$ EU project, Numerical Experimentation and Modeling of Materials and Structures of Low Environmental Impact, PROCAD/CAPES (2006 - 2010).

23. Lima, P.R.L., Leite, M.B., Santiago, E.Q.R., Recycled lightweight concrete made from footwear industry waste and CDW, Waste Management (Elmsford), 2010, 30, 1107-1113, https://doi.org/10.1016/j. wasman.2010.02.007.

24. Santiago, E.Q.R., Lima, P.R.L., Leite, M.B., Toledo Filho, R.D., Mechanical behavior of recycled lightweight concrete using EVA waste and CDW under moderate temperature, Revista IBRACON de Estruturas e Materiais, v.2, p. 211-221, 2009, https://doi. org/10.1590/S1983-41952009000300001.

25. Tacchard, A.L.R.S., Avaliaçăo da Resistência Mecânica de Argamassas de Cimento Portland Contendo Serragem de Couro Tratada em Meio Ácido, 2006, 121 p. Dissertaçăo (Mestrado em Engenharia de Materiais) - Universidade Federal de Săo Carlos, Săo Carlos.

26. Fujikawa, E.S., Incorporaçăo do resíduo "serragem cromada" em materiais de construçăo civil, 2002, 80 pp. Dissertaçăo (Mestrado em Engenharia Civil)-Universidade de Săo Paulo, Bauru.

27. Zăinescu, G., Deselnicu, V., Pang, X., Constantinescu, R., Albu, L., Deselnicu, D., Utilization of Sludge from Leather Tanning Residual Baths as Additive in Mortars, Proceedings of the 7th ICAMS 2018, pp. 539545, 18-20 October 2018, Bucharest, https:// doi.org/10.24264/icams-2018.X.8.

28. Zăinescu, G., Deselnicu, V., Constantinescu, R., Composite Structures Containing Leather Fibers with Applications in Constructions Industry, Proceedings of the 7th ICAMS 2018, pp. 593-598, 18-20 October 2018, Bucharest, https://doi.org/10.24264/icams-2018.XI.9.

29. Zainescu, G., Deselnicu, V., Constantinescu, R.R., Georgescu, D., New concept of bioconversion of tanned leather fibres with applications in the construction industry, 4th International Congress, Water, Waste and Energy Management, Madrid, Spain, 18-20 July 2018, ISBN 978-84-09-032389, Abstracts Book, 2018, p. 55.

30. Zăinescu, G., Deselnicu, V., Constantinescu, R.R., Georgescu, D., Biocomposites from tanned leather fibres with applications in constructions, Leather and Footwear Journal, 2018, 18, 4, 203-206, https://doi. org/10.24264/Ifj.18.3.4.

31. Zăinescu, G., Deselnicu, V., Constantinescu, R.R., Polymer compositions from leather fibres (leather shavings) for mortar in constructions, 18th SGEM International Scientific Multidisciplinary Conference on EARTH and Geo Sciences, 3 - 6 December, HOFBURG, Vienna, Austria, 2018.

(C) 2018 by the author(s). Published by INCDTPICPI, Bucharest, RO. This is an open access article distributed under the terms and conditions of the Creative Commons Attribution license (http:// creativecommons.org/licenses/by/4.0/). 